\title{
ОСОБЛИВОСТІ ПОВЕДІНКОВОГО ПІДХОДУ ДО ПРИЙНЯТТЯ УПРАВЛІНСЬКИХ РІШЕНЬ ФАХІВЦЯМИ З ФІНАНСІВ, ОБЛІКУ І ОПОДАТКУВАННЯ
}

Анотація. Метою статті е дослідження особливостей поведінкового підходу до прийняття управлінських рішень фрахівцями з фінансів, обліку і оподаткування. Доведення необхідності виділення в управлінні із загальної маси фрахівців галузі знань «Управління та адміністрування» саме фахівців з фрінансів, обліку і оподаткування як певної відмітної «економічної особистості». Проведено критичний аналіз економічної поведінки вищої ланки управління. Досліджено поведінковий підхід в управлінні з точки зору оцінки кваліфрікаційних якостей фрахівців з фінансів, обліку і оподаткування та менеджерів, яка наближена до ідей історичної школи політичної економії. Охарактеризовано моделі економічної поведінки типові для фрахівців з фрінансів, обліку і оподаткування та менеджерів. Встановлено, що управлінські рішення фрахівців з фрінансів, обліку і оподаткування насправді відрізняються від управлінських рішень менеджерів. Визначено особливості поведінкового підходу до прийняття управлінських рішень фрахівцями з фінансів, обліку і оподаткування, які є основним показником необхідності та доцільності розмежування підходу до управління класичного менеджера та зазначених фахівців. Представлено послідовність прийняття управлінського рішення у бізнесі фрахівцем з фінансів, обліку і оподаткування. Доведено, що різність підходів до управління фрахівців з фінансів, обліку і оподаткування та менеджерів виникає з відмінностей фрункціональних, професійних, кваліфікаційних можливостей та обов'язків. Менеджер виконуе схожі економічні функції, але центр ваги його дій знаходиться в області контролю і управління господарською діяльністю, тоді як на фрахівця з фінансів, обліку і оподаткування лягає фіксація первинної документації кожної господарської операції, чітке відображення її в обліку, арифметичний та логічний контроль проміжних та підсумкових звітів, підготовка стандартних фрорм звітності, відстеження змін податкового законодавства, положень та нормативних документів з грошового обігу, зовнішньоекономічної діяльності, поточний та перспективний економічний та фінансовий аналіз результатів господарської діяльності підприемства, розрахунок показників ліквідності, платоспроможності, рентабельності, ділової активності, фрінансової стійкості тощо на основі наявної управлінської та фрінансової звітності. Фахівець з фрінансів, обліку і оподаткування має достатній рівень кваліфікації задля здійснення управління господарською діяльністю завдяки здатності приймати «миттеві» управлінські рішення, що є доцільним, необхідним та обов’язковим з причини організації господарської діяльності в умах постійної зміни законодавчого поля, що в свою чергу впливає на стан і якість звітності, яка є основою прийняття усіх управлінських рішень.

Ключові слова: управління, менеджмент, поведінкова економіка, економічна поведінка, управлінські рішення, фахівець з фінансів, обліку і оподаткування, менеджер.

\section{Matvieiev Viacheslav, Matvieieva Olha, Shchepina Tetiana \\ National Aviation University}

\section{FEATURES OF BEHAVIORAL APPROACH IN MANAGEMENT DECISIONS MADE BY PROFESSIONALS IN FINANCE, ACCOUNTING AND TAXING}

Summary. The purpose of the article is to study the features of the behavioral approach to managerial decision-making by specialists in finance, accounting and taxation. Argumentation of the need to separate in management from the general mass of specialists in the field of knowledge "Management and Administration" precisely specialists in finance, accounting and taxation as a certain distinctive "economic personality". A critical analysis of the economic behavior of the top management level is carried out. The behavioral approach to management is investigated in terms of assessing the qualifications of specialists in finance, accounting and taxation, and managers, which is close to the ideas of the historical school of political economy. Models of economic behavior typical for specialists in finance, accounting and taxation, and managers are characterized. It was found that the managerial decisions of specialists in finance, accounting and taxation really differ from the managerial decisions of managers. The features of the behavioral approach to managerial decision-making by specialists in finance, accounting and taxation, which are the main indicator of the need and feasibility of differentiating the approach to management of a classic manager and these specialists, have been determined. The sequence of making management decisions in business by a specialist in finance, accounting and taxation is presented. It is proved that the difference in approaches to management of specialists in finance, accounting and taxation, and managers arises from differences in functional, professional, qualification capabilities and responsibilities. The manager performs similar economic functions, but the center of gravity of his actions is in the field of control and management of economic activities, while the specialist in finance, accounting and taxation is responsible for fixing the primary documentation of each business transaction, clearly reflecting it in the accounting, arithmetic and logical control of intermediate and final reports, preparation of standard reporting forms, tracking changes in tax legislation, regulations and regulatory documents of money circulation, foreign economic activity, current and future economic and financial analysis of the results of economic activities of the enterprise, calculation of liquidity indicators, solvency, profitability, business activity, financial stability, etc. .P. based on available management and financial reporting. A specialist in finance, accounting and taxation has a sufficient level of qualifications to manage economic activities due to the ability to make "instant" management decisions, which is advisable, necessary and necessary due to the organization of economic activities in conditions of constant changes in the legislative field, which in turn affects the state and the quality of reporting, which is the basis for all management decisions. Keywords: management, behavioral economics, economic behavior, management decisions, specialist in finance, accounting and taxation, manager. 
Постановка проблеми. У сучасних умо1 вах розвитку економіки найприкметніше багатьох наукових досліджень полягає у тому, що переконання учених-економістів збігаються у питанні необхідності виділення в управлінні із загальної маси фрахівців галузі знань «Управління та адміністрування» саме фрахівців з фрінансів, обліку і оподаткування як певної відмітної «економічної особистості». На думку учених-економістів необхідно розрізняти поведінковий підхід в управлінні зазначених фрахівців і поведінковий підхід в управлінні менеджера. Останній виконує схожі економічні фоннції, але центр ваги його дій знаходиться в області контролю і управління господарською діяльністю, тоді як на фрахівця 3 фінансів, обліку і оподаткування лягає фріксація первинної документації кожної господарської операції, чітке відображення її в обліку, арифметичний та логічний контроль проміжних та підсумкових звітів, підготовка стандартних форм звітності, відстеження змін податкового законодавства, положень та нормативних документів з грошового обігу, зовнішньоекономічноі діяльності, поточний та перспективний економічний та фрінансовий аналіз результатів господарської діяльності підприемства, розрахунок показників ліквідності, платоспроможності, рентабельності, ділової активності, фрінансової стійкості тощо на основі наявної управлінської та фрінансової звітності. Фахівець з фрінансів, обліку і оподаткування має достатній рівень кваліфрікації задля здійснення управління господарською діяльністю завдяки здатності приймати "миттеві» управлінські рішення, що є доцільним, необхідним та обов'язковим 3 причини організаціі господарської діяльності в умах постійної зміни законодавчого поля, що в свою чергу впливає на стан і якість звітності, яка є основою прийняття усіх управлінських рішень.

Аналіз основних досліджень і публікацій. Найзначнішими дослідженнями теоріі управління з погляду економічного розвитку є роботи австрійського економіста Йозефа Шумпетера, основоположника теорії управління з погляду економічного розвитку, одного з гігантів економічної науки, профресора Гарвардського університету. Ним була розглянута ізольована економіка, виділено три мотиви управлінської діяльності, досліджена теорія управління 3 достатньо оригінального погляду пояснення економічних криз через ідею ділових циклів. Американський вчений Девід Макклелланд висунув гіпотезу, згідно з якою індивідуальна економічна активність залежить від необхідності та доцільності досягнення цілей будь-якого порядку. Особливий внесок у дослідження теорії прийняття рішень було здійснено американським науковцем Музафером Шеріфом при розробці концепції досягнення екстраординарних цілей. Також, економічну поведінку в процесі прийняття управлінських рішень вивчали такі вчені, як: Є. Ходаківський, Ю. Богоявленська, Т. Грабар, В. Спасенніков, В. Комаровська, Г. Ложкін.

Постановка завдання. Критичний аналіз та ряд наукових робіт довели, що однією з причин низького рівня ефективності господарської діяльності є економічна поведінка вищої ланки управління. В результаті численних досліджень було встановлено, що управлінські рішення фахівців з фінансів, обліку і оподаткування насправді відрізняються від управлінських рішень менеджерів. Таким чином, особливості поведінкового підходу до прийняття управлінських рішень фахівцями з фрінансів, обліку і оподаткування є основним показником необхідності та доцільності розмежування підходу до управління класичного менеджера та зазначених фахівців. Сучасна економіка потребуе універсальних, кваліфікованих фрахівців з управління та адміністрування.

Виклад основного матеріалу дослідження. Традиція оцінки поведінкового підходу в управлінні підходить до ідей історичної школи політичної економії.

Фахівці з фінансів, обліку і оподаткування надалі по тексту - Фахівці.

Вважаеться, що основоположником теорії управління з погляду економічного розвитку є австрійський економіст Йозеф Шумпетер, один з гігантів економічної науки, який був професором Гарвардського університету. У своїй пращі «Теорія економічного розвитку» Йозеф Шумпетер розглядав ізольовану економіку, де мають місце в основному приватна власність, розподіл праці і вільна конкуренція. В ізольованій економіці виробництво слідуе за споживанням, а виробляти означае комбінувати матеріал, що є у розпорядженні виробників. Основна мета його роботи - це «дати логічно завершену модель господарських змін у часі». Йозеф Шумпетер вважав, що це неможливо зробити без вивчення бізнесу з погляду економічного розвитку. Згідно 3 теорією Йзефа Шумпетера Фахівещь - це рушійна сила економіки. Завдяки кваліфікації Фахівця запускаеться інвестиційний цикл, відкриваються можливості досягнення висот технічного прогресу, відродження економіки. Звичайно Фахівцю протидіють зовнішні фактори. Він впроваджуе новинки, але «новинки в економіці, як правило, впроваджуються не після того, як спочатку у споживача стихійно виникнуть нові потреби..., а лише тоді, коли саме виробництво прищепить споживачам нові потреби» [1, с. 216].

Йозефр Шумпетер виділяв три мотиви управлінської діяльності Фахівців:

у Фахівця високої кваліфікації прагнення до прийняття управлінських рішень з високим рівнем ефективності сильніше, ніж банальне прагнення до забезпечення фінансової стійкості;

максимізація прибутку підприемства для Фахівця є основним пріоритетом;

впровадження новітніх технологій, виробництво нових, раніше невідомих благ, використання нових джерел сировини, залучення нових джерел формування капіталу, забезпечення інтелектуального потенціалу, досягнення цілей будь-якого порядку тощо - усе це виступає метою управлінських рішень Фахівця.

Він стверджував, що 3 позищій інноващійного менеджменту Фахівець - перетворюючий лідер на відміну від лідера адміністративного менеджменту.

Теорія Йозефа Шумпетера є достатньо оригінальною з погляду пояснення економічних криз через ідею ділових циклів [1, с. 221].

Американський вчений Девід Макклелланд висунув гіпотезу, згідно з якою індивідуальна 
економічна активність залежить від необхідності та доцільності досягнення цілей будь-якого порядку. Чим вищий рівень зазначеної необхідності та доцільності, тим вищий рівень едективності бізнесу. Шляхом різних експериментальних досліджень Девід Макклелланд і його команда науковців-дослідників запропонували методику визначення кількісних параметрів необхідності та доцільності досягнення цілей будь-якого порядку. Надалі була встановлена кореляція між високим рівнем необхідності та доцільності досягнення цілей будь-якого порядку i ефрективністю бізнесу. Девід Макклелланд вважав, що ключовою якістю Фахівця є прагнення до нововведень, впроваджених в результаті комплексного аналізу досліджень експертів. На його думку у Фахівця достатньо своєрідне ставлення до грошей, їхня цінність полягає в їх едективності як засобу досягнення цілей будь-якого порядку, а самоцінність грошей для Фахівця невисока. Девід Макклелланд також виділяв як провідний мотив - прагнення Фахівця до економічної незалежності та високого рівня ефективності бізнесу, створення капіталу [1, с. 236].

Проте, не дивлячись на такий грунтовний фрундамент, теорія управління розвивалася, розглядаючи Фахівців як другорядних після менеджерів. Перелом відбувся в процесі розвитку економіки, коли до управління господарською діяльністю не менеджером, а саме Фахівцем різко зріс інтерес ні з боку науки, а з боку ділових кіл. Головна причина такого інтересу була обумовлена динамікою економічних процесів у Сполучених Штатах Америки, коли американські вчені-економісти і практики помітили тривожну тенденцію в структурі інвестицій найбільших корпорацій (високий рівень інвестицій у короткострокові проекти з мінімальним ступенем ризику i практично нульове інвестування у довгострокові високоліквідні проекти з гранично допустимим ступенем обгрунтованого ризику). Критичний аналіз та ряд досліджень довели, що однією 3 причин була економічна поведінка вищої ланки управління корпорацій. Менеджери великих корпорацій прагнули перш за все до зміцнення своїх особистих позицій, несучи відповідальність за фонінансовий стан і виплату дивідендів, вони вважали за краще мінімізувати ступінь ризику i орієнтувалися на короткострокові проекти, які приносили стабільні доходи. Тим самим з виробничих програм корпорацій поступово зникали інноваційні, високоліквідні, довгострокові проекти, що вимагали ризику. Також слід зазначити, що усередині корпорацій Фахівці, які демонстрували схильність до нововведень і нестандартних управлінських рішень, виявилися важко сумісними 3 ієрархічною системою вертикального підпорядкування. Таким чином, в результаті численних досліджень було встановлено, що управлінські рішення Фахівців насправді відрізняються від управлінських рішень менеджерів великих корпорацій. Нові підприемства, де управлінські рішення приймалися Фахівцями, здійснювали прориви в ризикових, технологічно складних галузях, стимулюючи тим самим не лише науково-технічний прогрес, a i змінюючи фрінансовий ринок, спонукаючи потенційних інвесторів до вкладень в інноваційне виробництво.
Доцільно виділити моделі економічної поведінки типові для Фахівців і менеджерів, наведені у дослідженнях фрранцузького Агентства 3 питань наукових досліджень:

мотивація Фахівця грунтуеться на прагненні до економічної незалежності підприемства; він може замінити економіста будь-якої спеціалізації; оцінюе суть економічних відносин, а не структуру управління ними; враховує перш за все новітні технології і ринки; вираховуе ймовірність і ступень ризику; має достатню кваліфрікацію задля організації та здійснення інвестиційної та інноваційної діяльності;

класичний менеджер мотивуеться перш за все прагненням до влади, фрактично весь його час займає керування; головним вважає профресійне управління, звертає увагу на атмосферу, що панує усередині підприемства; для нього велике значення має робоче місце (який у нього кабінет, на якому поверсі він розташований і таке інше); прагне уникати будь-яких змін, неочікуваного або нововведень; визнання власних управлінських рішень неефективними не допускає ні в якому разі $[2$, с. $29 ; 3$, с. 18$]$.

Важливим є зазначити, що інколи чітких меж між Фахівцями і менеджерами може зовсім не бути, а також Фахівець і менеджер можуть бути представлені в одній особі.

У бізнесі Фахівець 3 достатнім рівнем кваліфікащії має можливість прийняти ефективне управлінське рішення та забезпечити організацію, здійснення господарської діяльності, пристосуватися до нових умов ведення господарської діяльності, приймаючи «миттеві» управлінські рішення, що $є$ доцільним, необхідним та обов'язковим 3 причини організації господарської діяльності в умах постійної зміни законодавчого поля, поєднуючи власні функціональні обов'язки 3 функціональними обов'язками менеджера, дотримуючись певної послідовності прийняття управлінського рішення:

мотив;

мета;

необхідність;

доцільність (окрема операція щодо якої приймається управлінське рішення може бути необхідна, але недоцільна - у такому випадку ефективним управлінським рішенням вважається відмова від подальших дій, тобто від здійснення окремої операції);

планування;

прогнозування;

аналіз інформації

проведення необхідних розрахунків;

прийняття управлінського рішення;

дія (впровадження заходів, здійснення операції, підписання угоди, реалізація інвестиційного проекту, залучення позикового капіталу і таке інше);

арифрметичний та логічний контроль;

поточний та перспективний економічний та фрінансовий аналіз результатів;

розрахунок показників ліквідності, платоспроможності, рентабельності, ділової активності, фрінансової стійкості тощо;

корекція дій;

удосконалення (здійснення нових комбінацій, при цьому нова комбінація повинна містити необхідні їй складові з тієї або іншої старої ком- 
бінаціі, і це є фрормою забезпечення конкурентоспроможності) [4, с. 42].

Таким чином, особливості поведінкового підходу до прийняття управлінських рішень фрахівцями 3 фрінансів, обліку і оподаткування є основним показником необхідності та доцільності розмежування підходу до управління класичного менеджера та зазначених фрахівців. Сучасна економіка потребує універсальних, кваліфікованих фахівців з управління та адміністрування. Узагальнений особистісний портрет кваліфрікованого фрахівця 3 фрінансів, обліку і оподаткування включає переважно профресійні, ділові, інтелектуальні, комунікативні, вольові якості, необхідні задля забезпечення високого рівня ефективності господарської діяльності. Загальна характеристика, 3 урахуванням поведінкової економіки, фрахівця 3 фрінансів, обліку і оподаткування як управлінця полягає у виділенні його психологічних якостей, кваліфікаційного рівня, теоретичних знань та професійних навичок, які розкривають можливості автономного ухвалення і здійснення "миттевого» управлінського рішення, що є доцільним, необхідним та обов'язковим 3 причини організації господарської діяльності в умах постійної зміни законодавчого поля, з пошуку і використовування нових економічних можливостей підприемства в умовах ризику з метою максимізації прибутку.

Висновки 3 проведеного дослідження. Узагальнюючи вищезазначене, можна стверджувати наступне:

управлінські рішення фрахівців з фінансів, обліку і оподаткування відрізняються від управлінських рішень класичних менеджерів та забезпечують здійснення проривів у ризикових, технологічно складних галузях, стимулюючи тим самим не лише науково-технічний прогрес, а і змінюючи фрінансовий ринок, спонукаючи потенщійних інвесторів до вкладень в інноваційне виробництво, в інноваційні, високоліквідні, довгострокові проекти; мотивація фрахівця 3 фрінансів, обліку і оподаткування грунтуеться на прагненні до економічної незалежності бізнесу; він може замінити економіста будь-якої спеціалізації; оцінюе суть економічних відносин, а не структуру управління ними; враховуе новітні технології і ринки; вираховує ймовірність і ступень ризику; має достатню кваліфікацію задля організації та здійснення інвестиційної та інноваційної діяльності;

кваліфікація фрахівця з фінансів, обліку і оподаткування запускає інвестиційний цикл, відкриває можливості досягнення висот технічного прогресу, відродження економіки;

основним пріоритетом фрахівця з фрінансів, обліку і оподаткування $е$ максимізація прибутку підприемства;

впровадження новітніх технологій, виробництво нових, раніше невідомих благ, використання нових джерел сировини, залучення нових джерел формування капіталу, забезпечення інтелектуального потенціалу, досягнення цілей будь-якого порядку тощо - усе це виступає метою управлінських рішень фрахівця з фрінансів, обліку і оподаткування;

3 позицій інноваційного менеджменту фрахівець 3 фінансів, обліку і оподаткування - перетворюючий лідер на відміну від лідера адміністративного менеджменту.

Таким чином, у бізнесі фрахівець 3 фрінансів, обліку і оподаткування 3 достатнім рівнем кваліфікації має можливість прийняти ефективне управлінське рішення та забезпечити організацію, здійснення господарської діяльності, пристосуватися до нових умов ведення господарської діяльності, приймаючи «миттеві» управлінські рішення, що $є$ дощільним, необхідним та обов'язковим 3 причини організації господарської діяльності в умах постійної зміни законодавчого поля, поєднуючи власні функціональні обов'язки 3 фрункціональними обов’язками менеджера.

\section{Список літератури:}

1. Ложкін Г.В., Спасєнніков В.В., Комаровська В.Л. Економічна психологія : навчальний посібник. Київ : ВД «Профресіонал», 2014. 304 с.

2. Андреева К.П. Основы менеджмента: практическое обозрение терминологии. Київ : Менеджмент и Управление, 2014. 234 с.

3. Ходаківський Є.І. Психологія управління : навчальний посібник. Київ : Центр учбової літератури, 2016.492 с.

4. Алюшина Н.О. Психологічні механізми ефективного управлінського впливу : навчально-методичні матеріали. Київ : НАДУ, 2013. 48 с.

\section{References:}

1. Lozhkin H.V., Spasiennikov V.V., Komarovska V.L. (2014) Ekonomichna psykholohiia [Economic psychology]. Kyiv: VD «Profesional». (in Ukrainian)

2. Andreeva K.P. (2014) Osnovy menedzhmenta [Fundamentals of management]. Kyiv: Menedzhment i Upravlenie. (in Ukrainian)

3. Khodakivskyi Ye.I. (2016) Psykholohiia upravlinnia [Management psychology]. Kyiv: Tsentr uchbovoi literatury. (in Ukrainian)

4. Aliushyna N.O. (2013) Psykholohichni mekhanizmy efektyvnoho upravlinskoho vplyvu [Psychological mechanisms of effective managerial influence]. Kyiv: NADU. (in Ukrainian) 